\title{
Effect of Social Media Applications on Kuwaiti Teenagers: An Empirical Study
}

\author{
Mahdy I. Aljazzaf* \\ Kuwait University, College of Business, QMMIS Department, Kuwait City, Kuwait \\ *Corresponding author: maljazzaf@hotmail.com
}

\begin{abstract}
Teenagers in Kuwait and elsewhere spend a lot of their time using various types of social media applications (SMA). This study surveyed Kuwaiti teenagers, males and females at different educational levels, the usage intensity, purpose of use of these applications and quantitatively assessed the effect it has on many dimensions of their life. Many interesting results are highlighted and can be extrapolated to teens in the Arab World and beyond. The most outstanding results are that Kuwait teenagers spend a lot of time using social media applications, use WhatsApp and Snapchat in particular for communicating with others and for entertainment, it has negatively affected their sleeping hours, consider it a very useful learning resource, by in large trust the information received on social media, do not seem to be over concerned about how it affects their privacy, use it quite often to buy products and services, and they are satisfied with such purchases. To achieve these goals, a special questionnaire has been prepared especially for this purpose has been met from a random sample of Kuwait teens from different schools in Kuwait. Appropriate statistical analysis tools were used in this study.
\end{abstract}

Keywords: Kuwaiti teens, social media, impact of SMA, SMA usage, SMA effects, quantitative analysis, independency tests, differences tests

Cite This Article: Mahdy I. Aljazzaf, "Effect of Social Media Applications on Kuwaiti Teenagers: An Empirical Study." American Journal of Applied Mathematics and Statistics, vol. 5, no. 4 (2017): 145-153. doi: 10.12691/ajams-5-4-5.

\section{Introduction and Background}

A 2009 study [1] showed that $93 \%$ of American teenagers between 12 and 17 , boys and girls alike, go online, a number that has remained stable since 2006 and nearly two thirds of teens go online every day and $26 \%$ of them go online several times a day. Today, with the wider penetration of smart phones and greater mobile internet connectivity, it is natural to expect that more teens use the internet and social media applications (SMA) like WhatsApp, Snapchat, Instagram, and Twitter than ever before. Therefore, it should be of interest to study various aspects of teen's usage of SMA and how it is affecting them both positively and negatively $[2,3]$.

There are very few studies about Arab teenager's SMA use and impact see for example [4,5]. The objectives of this study is to assess Kuwaiti teen's (KT) usage level, purpose-of-use, and positive and negative consequences related to the use of the most popular SMA. This study examines these aspects through a field survey that covers male and female teens in three educational levels.

\section{Objectives and Importance}

The importance of this research is that it aims to study and analyze the effect of social media applications on Kuwait teens (KTs) by examining many aspects: assess usage level, purpose-of-use, and positive and negative impacts related to the use of the most popular SMAs, through a field survey that covers male and female teens in three educational levels. More specifically, this research aims to:

1. Estimate the percentages of personal information which is represented by the age of the student, gender and educational levels.

2. Examine the relationship between the aspects of this study which are to assess Kuwaiti teen's (KT) usage level, purpose-of-use, and positive and negative consequences related to the use of the most popular SMA among the Kuwait teens.

3. Examine the relationship between the aspects of this study which are to assess Kuwaiti teen's (KT) usage level, purpose-of-use, and positive and negative consequences related to the use of the most popular SMA from the Kuwait teens' point of view.

\section{Study Sample and Procedures}

The Population: The study population is the Kuwait teens in the Mid-School level, High-School level, and College level.

The Sample: The study sample consisted of a simple random sample of 402 participants from the Kuwait teens defined in the population. The study questionnaire was distributed at (420) participants of the study population, where (402) of them are valid and the other (18) are 
excluded due to the lack of validity, making the response rate up to $95.7 \%$, which is a high response rate. See Table 1 below:

Table 1. Breakdown of Kuwaiti teens surveyed by gender, education level, and age

\begin{tabular}{|c|c|c|}
\hline Category & Subcategory & No. Surveyed \\
\hline \multirow{2}{*}{ Gender } & Males & $198(49 \%)$ \\
\cline { 2 - 3 } & Females & $205(51 \%)$ \\
\hline \multirow{3}{*}{$\begin{array}{c}\text { Educational } \\
\text { Level }\end{array}$} & Middle-School & $117(29 \%)$ \\
\cline { 2 - 3 } & Secondary School & $157(39 \%)$ \\
\cline { 2 - 3 } & College & $129(32 \%)$ \\
\hline \multirow{5}{*}{ Age } & 13 & $28(7 \%)$ \\
\cline { 2 - 3 } & 14 & $65(16 \%)$ \\
\cline { 2 - 3 } & 15 & $77(19 \%)$ \\
\cline { 2 - 3 } & 16 & $47(12 \%)$ \\
\cline { 2 - 3 } & 17 & $56(14 \%)$ \\
\cline { 2 - 3 } & 18 & $69(17 \%)$ \\
\hline \multirow{7}{*}{} & 19 & $61(15 \%)$ \\
\hline
\end{tabular}

The study Tool: It is consisted of a questionnaire of two parts, where the first part included a set of questions dealt with the personal information of age: from 13 to 19 years, gender: male and female, and educational levels: mid-school, high-school, and college level of the Kuwait teens. And the second part of the study group questions related directly and indirectly to the effect of social media applications on Kuwait teens, which are represented as follows:

1. The top five social media applications used in Kuwait: WhatsApp, Snapchat, YouTube, Instagram, and Twitter.

2. The usage of social media applications which are the following: Communication with others, Viewing and exchanging pictures and videos, Entertainment, Following up sports, Buying and selling products and services, Following up fashion, and Learning and general education.

3. The impacts of social media applications on the Kuwaiti teens taking into account the times spent on using these SMA which consists of "What is the average time you spend daily using social media applications?", "What is the average time you spend daily interacting with your family?", "What is the average number of hours you sleep each day?", "Does using SMA affect your sleeping hours?", "Does SM negatively affect your studying?", Does SM negatively affect your eating habits?", "Do you consider SM the best mean to communicate with your family?", "Do you agree that SM is the easiest way to make new relationships with others?", "To what extend you trust the information you obtain from SM?", "Does SM affect your privacy and your daily behavior?", "To what extend do you buy products or services through SM?", and "To what extend did you buy products or services that you did not actually need through SM?". Note that the first three questions related to the sub item of times spent on using the SMA.

Tool Reliability and Validity: In order to ensure the validity of the study tool, the questionnaire was initially distributed to five faculty members from the Faculty of Business Administration at Kuwait University, and asked them to express an opinion on the suitability of the tool for the study sample and the safety of the appropriate language and how the study questions are suitable for members of the sample. And the tool thereafter was amended according to the faculty members' remarks and notes where some of those remarks were positive and some were negative ones.
For the purpose of ascertaining the external validity of the tool, the amended questionnaire was distributed to 50 participants of the population as a pilot sample to ensure clarity and extent of respond to it. Some have made remarks on lack of clarity of some questions and then the tool was amended again.

In order to ensure the stability of the tool, the reliability coefficient (Krumbach Alpha) is calculated and found to be close to 0.911 , which is high stability, and refers to an excellent degree of questions consistency. Then a group of students, who have been trained, were asked to distribute the questionnaire randomly to Kuwaiti teens.

\section{Statistical Analysis}

The SPSS statistical package was used in the statistical analysis to calculate the appropriate statistics such as the following:

1. Percentages and ratios through the frequency tables which used to calculate the percentages of personal information and the study variables.

2. The Chi square test of independence, which was used to know some of the relationships between the personal data and the study variables as described in the study objectives.

3. The Analysis of variance ANOVA test, which was used to test for the significant differences among the mean responses for the study variables as described in the study objectives according to the personal information.

\section{Study Results and discussion}

\subsection{The Study Variables and the Extent of their Relationship with each other and with the Personal Information}

\subsubsection{SMAs used by Kuwait Teenagers}

The results indicate that Kuwaiti teens (KTs): intensively use WhatsApp and Snapchat, moderately use YouTube and Instagram, and lightly use Twitter, see Figure 1 below. When results were examined across gender, it is found that a higher proportion of females (56\%) intensively used Snapchat than males (only 37\%). Since the main distinguishing feature of Snapchat is sharing pictures and videos, it can be concluded that more females like to "share the moment" through pictures and videos than males. The percentages of use levels for the remaining four SMAs were found to be very close among males and females.

When results were examined across educational levels, it is observed that the intensive use level for college teens was WhatsApp at $74 \%$, while for secondary and middle school it was Snapchat at $80 \%$ and at $68 \%$, respectively. Furthermore, it is observed that the intensive use of Snapchat was highest among secondary school teens at $80 \%$, compared with $71 \%$ for college and $68 \%$ for middle school students. Lastly, it is observed that the lowest level of Twitter use was among middle school teens at $56 \%$, followed by secondary teens at $41 \%$ and college teens at $39 \%$. 


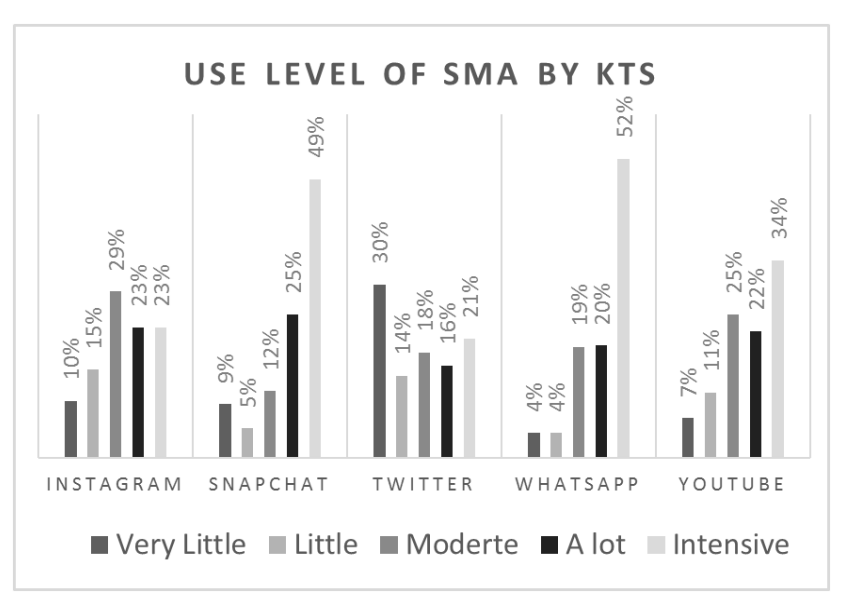

Figure 1. Use level of social media applications by Kuwait teenagers.

\subsubsection{Main Uses of SMA}

As Figure 2 below shows, the top-3 uses of SMA by KTs are found to be: communicate with others $(45 \%)$, entertainment (45\%), and view pictures and videos $(29 \%)$, while the least-3 uses are found to be: buy \& sell (52\%), watch sports $(16 \%)$, and study \& education $(32 \%)$. It is not surprising to see communicating with others and entertainment were among the top-3 intense uses of SMA, however, to see almost one third of KTs hardly use these SMA, in particular YouTube, for study \& education is rather disappointing.

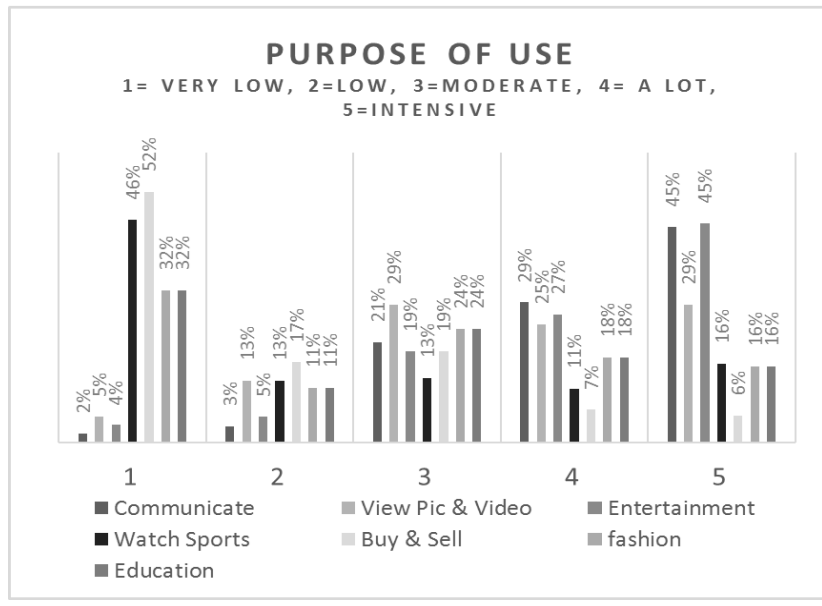

Figure 2. Purpose of use of social media applications by Kuwait teenagers.

When results were analyzed with respect to gender, as one might expect, females use SMA more for fashion than males, and also males use SMA more for sports than females. It is also observed that about two thirds of females spend a lot of time communicating with others, whereas less than half of the males do so. No clear variations were observed in SMA's purpose of use across the three educational levels.

It is to be noted that though communicating with others seems to be a good utilization of SMA, excessive chatting can lead to health problems, refer to [6].

\subsubsection{Impact of using SMA}

\section{a) The Time Dimension}

Three dimensions of time were surveyed in this study, refer to the study tool above. The results are summarized in Table 2 and Table 3 below.
It is observed that, irrespective of gender or educational levels, about one half of the KTs spend on average more than 3 hours per day using SMA, and about a quarter of them spend on average 2-3 hours per day using SMA. So more than three quarters of teens spend two or more hours every day using SMA. This is quite a significant time.

On the other hand, less than one third of KTs spend on average more than 3 hours per day interacting with their family members with clear distinction between males $(16 \%)$ and females $(37 \%)$ teens. Most of the male teens (56\%) spend on average 'less than two hours each day with their families while most of female teens $(65 \%)$ spend on average more than two hours with their families.

Table 2. Percent of Average daily time spent using SMA and interacting with family by Kuwaiti teens

\begin{tabular}{|c|c|c|c|c|c|c|}
\hline & & 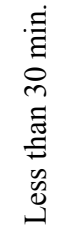 & 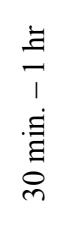 & $\begin{array}{l}\stackrel{\mathscr{U}}{\Xi} \\
\stackrel{1}{1}\end{array}$ & $\frac{\mathscr{E}}{\stackrel{\Xi}{c}}$ & 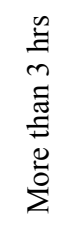 \\
\hline \multirow{6}{*}{$\begin{array}{c}\text { Average } \\
\text { Daily } \\
\text { Time } \\
\text { spent } \\
\text { Using SM }\end{array}$} & Aggregate & $1 \%$ & $6 \%$ & $14 \%$ & $24 \%$ & $56 \%$ \\
\hline & Male & $1 \%$ & $10 \%$ & $16 \%$ & $24 \%$ & $49 \%$ \\
\hline & Female & $1 \%$ & $3 \%$ & $12 \%$ & $24 \%$ & $60 \%$ \\
\hline & Middle-School & $2 \%$ & $8 \%$ & $16 \%$ & $28 \%$ & $46 \%$ \\
\hline & Secondary & $1 \%$ & $4 \%$ & $8 \%$ & $24 \%$ & $63 \%$ \\
\hline & College & $2 \%$ & $6 \%$ & $18 \%$ & $19 \%$ & $55 \%$ \\
\hline \multirow{6}{*}{$\begin{array}{c}\text { Average } \\
\text { Daily } \\
\text { Time } \\
\text { spent } \\
\text { Interact } \\
\text { with } \\
\text { Family }\end{array}$} & Aggregate & $9 \%$ & $10 \%$ & $24 \%$ & $28 \%$ & $28 \%$ \\
\hline & Male & $9 \%$ & $13 \%$ & $34 \%$ & $29 \%$ & $16 \%$ \\
\hline & Female & $8 \%$ & $9 \%$ & $18 \%$ & $28 \%$ & $37 \%$ \\
\hline & Middle-School & $10 \%$ & $11 \%$ & $24 \%$ & $34 \%$ & $21 \%$ \\
\hline & Secondary & $5 \%$ & $8 \%$ & $29 \%$ & $22 \%$ & $36 \%$ \\
\hline & College & $12 \%$ & $13 \%$ & $18 \%$ & $31 \%$ & $26 \%$ \\
\hline
\end{tabular}

Table 3. Percent of Average daily time spent sleeping by teens.

\begin{tabular}{|c|c|c|c|c|c|c|}
\hline & & 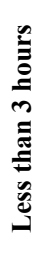 & $\frac{n}{3}$ & 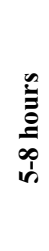 & $\frac{\mathscr{a}}{\stackrel{\Xi}{\Xi}}$ & 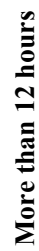 \\
\hline \multirow{6}{*}{$\begin{array}{c}\text { Average } \\
\text { Time } \\
\text { spent } \\
\text { Sleeping }\end{array}$} & Aggregate & 1 & 10 & 35 & 35 & 19 \\
\hline & Male & 1 & 9 & 39 & 30 & 22 \\
\hline & Female & 2 & 11 & 32 & 38 & 18 \\
\hline & Middle-School & 2 & 5 & 38 & 44 & 12 \\
\hline & Secondary & 2 & 13 & 36 & 24 & 25 \\
\hline & College & 0 & 10 & 30 & 41 & 19 \\
\hline
\end{tabular}

The vast majority (89\%) of the Kuwaiti teens, males and females alike, sleep on average 5 or more hours each day. This is quite a healthy sign. However, a small percentage $(11 \%)$ of the teens sleeps less than 5 hours each day. However, there might be an "over-sleeping" problem with Kuwaiti teens because about one fifth of them sleep more than 12 hours per day. This warrants a further investigation.

b) Communication with Family

Nearly one half of the KTs, irrespective of their gender or educational level, do not consider SMA to be the best 
way to communicate with their families, compared with nearly one sixth of them who find it the best way to do so, refer to Table 4.

Table 4. Percent of Teen's communicating with family using SMA

\begin{tabular}{|c|c|c|c|c|c|c|}
\hline & & 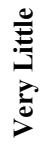 & 兽 & 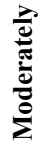 & $\frac{\vec{c}}{4}$ & 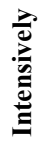 \\
\hline \multirow{6}{*}{$\begin{array}{l}\text { Do you consider } \\
\text { SMA the best } \\
\text { Mean to } \\
\text { commun-icate } \\
\text { with your } \\
\text { family? }\end{array}$} & Aggregate & 29 & 16 & 25 & 17 & 14 \\
\hline & Male & 32 & 16 & 20 & 18 & 14 \\
\hline & Female & 26 & 16 & 28 & 16 & 14 \\
\hline & Middle-School & 20 & 15 & 26 & 25 & 15 \\
\hline & Secondary & 33 & 14 & 26 & 10 & 17 \\
\hline & College & 32 & 18 & 23 & 18 & 9 \\
\hline
\end{tabular}

\section{c) SMA Effect on Sleeping hours}

Irrespective of gender or educational levels, nearly half one of KTs strongly feel that the use of SMA negatively affects their sleeping hours. Only about one fifth of KTs feel that use of SMA has little effect on their sleeping hours. No variations in responses were observed across gender or educational levels, see Table 5.

Table 5. Percent of Teen's perception on how use of SMA affects their sleeping hours

\begin{tabular}{|c|c|c|c|c|c|c|}
\hline & & 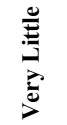 & 苞 & 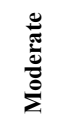 & $\frac{\vec{\theta}}{4}$ & 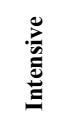 \\
\hline \multirow{6}{*}{ 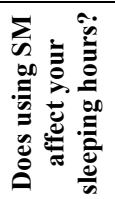 } & Aggregate & $17 \%$ & $14 \%$ & $25 \%$ & $19 \%$ & $26 \%$ \\
\hline & Male & $12 \%$ & $12 \%$ & $28 \%$ & $19 \%$ & $29 \%$ \\
\hline & Female & $20 \%$ & $16 \%$ & $22 \%$ & $19 \%$ & $24 \%$ \\
\hline & Middle School & $19 \%$ & $14 \%$ & $28 \%$ & $20 \%$ & $20 \%$ \\
\hline & Secondary & $17 \%$ & $16 \%$ & $20 \%$ & $16 \%$ & $30 \%$ \\
\hline & College & $14 \%$ & $13 \%$ & $17 \%$ & $22 \%$ & $25 \%$ \\
\hline
\end{tabular}

\section{d) SMA Effect on Studying}

Nearly two thirds of the Kuwaiti teens feel that the use of SMA moderately to intensively affects their hours of studying, about a quarter of them feel it affects them moderately, and one sixth of them feel it affects them intensively. Only one fifth of them feel this effect is very little, see Table 6.

Furthermore, more females $(25 \%)$ feel that it has a very little effect compared with only $16 \%$ of the males who feel that. It is also observed that a higher proportion (30\%) of middle school KTs feel that the use of SMA has very little effect on studying compared with only $13 \%$ of college teens and $22 \%$ of secondary school teens.

Table 6. Percent of Teen's perception on how use of SMA negatively affects their studying hours

\begin{tabular}{|c|c|c|c|c|c|c|}
\hline & & 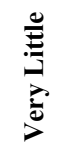 & $\stackrel{0}{\Xi}$ & 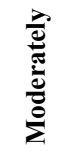 & $\frac{\vec{\theta}}{4}$ & 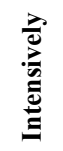 \\
\hline \multirow{6}{*}{$\begin{array}{c}\text { Does } \\
\text { SMA } \\
\text { negatively } \\
\text { affect } \\
\text { your } \\
\text { studying? }\end{array}$} & Aggregate & $21 \%$ & $18 \%$ & $26 \%$ & $19 \%$ & $16 \%$ \\
\hline & Male & $16 \%$ & $16 \%$ & $23 \%$ & $22 \%$ & $23 \%$ \\
\hline & Female & $25 \%$ & $19 \%$ & $27 \%$ & $17 \%$ & $11 \%$ \\
\hline & Middle-School & $30 \%$ & $17 \%$ & $20 \%$ & $20 \%$ & $14 \%$ \\
\hline & Secondary & $22 \%$ & $17 \%$ & $25 \%$ & $19 \%$ & $17 \%$ \\
\hline & College & $13 \%$ & $20 \%$ & $33 \%$ & $20 \%$ & $15 \%$ \\
\hline
\end{tabular}

\section{e) SMA Effect on Eating Habits}

Table 7 shows the effect of using SMA has on teen's eating habits. It clearly shows that, irrespective of gender or educational level, the majority feel it has either little or very little negative impact on their eating habits. Only one tenth of them feel that the use of SMA has intense impact on their eating habits.

More males (48\%) feel that the use of SMA has a lot to intense impact on their eating habits compared with females $(22 \%)$ who feel that. Few secondary school teens $(7 \%)$ feel that the use of SMA has a negative intense impact on their eating habit compared with middle school $(15 \%)$ and college teens $(11 \%)$

Table 7. Percent of Teen's perception on how use of SMA affects their eating habits

\begin{tabular}{|c|c|c|c|c|c|c|}
\hline & & 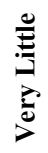 & 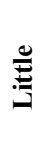 & $\frac{\frac{2}{0}}{\frac{\pi}{0}}$ & $\frac{\overrightarrow{0}}{4}$ & 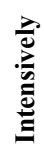 \\
\hline \multirow{6}{*}{$\begin{array}{c}\text { Does SM } \\
\text { negatively } \\
\text { affect your } \\
\text { eating } \\
\text { habits? }\end{array}$} & Aggregate & 38 & 16 & 18 & 18 & 10 \\
\hline & Male & 35 & 11 & 16 & 22 & 16 \\
\hline & Female & 40 & 19 & 19 & 15 & 7 \\
\hline & Middle-School & 32 & 14 & 18 & 21 & 15 \\
\hline & Secondary & 46 & 17 & 16 & 14 & 7 \\
\hline & College & 34 & 16 & 21 & 18 & 11 \\
\hline
\end{tabular}

\section{f) Trusting information on SMA}

Close to half of the KTs, irrespective of their gender or educational level, moderately trust the information they get from SMA, while one quarter of them trust SMA a lot or intensively, and one quarter trust little or very little. There is a clear symmetry or balance in this regard, see Table 8.

No significant gender variations are observed in trusting the information received from the SMA. However, it is noted that less college and secondary level KTs trust the information obtained from than middle school level teens. So younger teenagers seem to trust the information obtained from SM more than older teens.

Table 8. Percent of Teen's level of trust about the information presented by SMA

\begin{tabular}{|c|c|c|c|c|c|c|}
\hline & & & 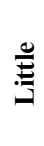 & $\frac{\frac{\lambda}{d}}{\frac{\pi}{\pi}}$ & $\stackrel{\bullet}{\iota}$ & 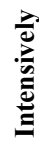 \\
\hline \multirow{6}{*}{$\begin{array}{l}\text { To what extend } \\
\text { do you } \\
\text { trust the inform } \\
\text { ation you obtain } \\
\text { from } \\
\text { SMA? }\end{array}$} & Aggregate & 11 & 16 & 46 & 16 & 10 \\
\hline & Male & 12 & 16 & 40 & 22 & 11 \\
\hline & Female & 11 & 17 & 50 & 12 & 10 \\
\hline & Middle-School & 7 & 8 & 48 & 21 & 15 \\
\hline & Secondary & 12 & 20 & 46 & 13 & 9 \\
\hline & College & 14 & 20 & 44 & 17 & 5 \\
\hline
\end{tabular}

\section{g) SMA \& Privacy}

The majority of KTs feel that the use of SMA does not affect their privacy. About a quarter of teens feel that it has a moderate effect on their privacy, see Table 9.

It is worth mentioning that more males $(37 \%)$ felt that their privacy has been affected a lot or intensively compared with only $20 \%$ of the females. It is also noted that $55 \%$ of college teens KTs seem to feel their privacy 
has been either affected little or very little, compared with $47 \%$ for secondary and $43 \%$ middle school levels. So it seems older teens seem to be a bit less concerned about how SMA affects their privacy than younger teens.

Table 9. Percent of Teen's perception of how SMA affects their privacy

\begin{tabular}{|c|c|c|c|c|c|c|}
\hline & & 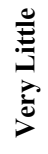 & 莺 & 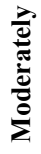 & $\frac{\overrightarrow{0}}{4}$ & 常 \\
\hline \multirow{6}{*}{$\begin{array}{l}\text { Does the } \\
\text { use of } \\
\text { SMA } \\
\text { affect } \\
\text { your } \\
\text { privacy? }\end{array}$} & Aggregate & 27 & 21 & 25 & 19 & 8 \\
\hline & Male & 22 & 19 & 22 & 27 & 10 \\
\hline & Female & 30 & 23 & 26 & 13 & 7 \\
\hline & Middle-School & 22 & 21 & 25 & 21 & 10 \\
\hline & Secondary & 30 & 17 & 26 & 17 & 10 \\
\hline & College & 28 & 27 & 23 & 18 & 5 \\
\hline
\end{tabular}

h) Buying Products and Services through SMA

KTs were asked two questions with regard to buying products or services through SMA. The results are shown in Table 10 and Table 11, respectively.

Table 10. Percent of teens buying products or services through SMA

\begin{tabular}{|c|c|c|c|c|c|c|}
\hline & & 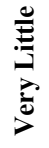 & : & 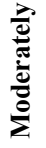 & $\stackrel{\overrightarrow{0}}{4}$ & 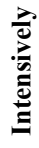 \\
\hline \multirow{6}{*}{$\begin{array}{c}\text { To what } \\
\text { extend do } \\
\text { you buy } \\
\text { products } \\
\text { or services } \\
\text { through } \\
\text { SMA? }\end{array}$} & Aggregate & 22 & 20 & 27 & 17 & 13 \\
\hline & Male & 25 & 21 & 25 & 19 & 11 \\
\hline & Female & 21 & 20 & 28 & 17 & 15 \\
\hline & Middle-School & 21 & 21 & 22 & 22 & 15 \\
\hline & Secondary & 21 & 20 & 25 & 16 & 17 \\
\hline & College & 26 & 21 & 33 & 14 & 7 \\
\hline
\end{tabular}

About one third of KTs buy products and service through SMA either a lot or intensively, and about half of them buy little or very little. No gender variations are observed in this regard but younger teens (middle school) seem to buy more than the older ones (secondary and college levels).

Table 11. Percent of teens buying products or services through SMA that they do not need

\begin{tabular}{|c|c|c|c|c|c|c|}
\hline & & 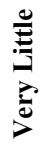 & $\stackrel{0}{:}$ & 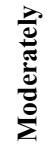 & $\frac{\overrightarrow{0}}{4}$ & $\begin{array}{l}\frac{\lambda}{0} \\
\frac{\overrightarrow{0}}{0} \\
\stackrel{\Xi}{\Xi}\end{array}$ \\
\hline \multirow{6}{*}{$\begin{array}{c}\text { To what } \\
\text { extend did you } \\
\text { buy products } \\
\text { or services } \\
\text { that you did } \\
\text { not actually } \\
\text { need through } \\
\text { SMA? }\end{array}$} & Aggregate & 40 & 18 & 18 & 13 & 11 \\
\hline & Male & 43 & 18 & 14 & 14 & 10 \\
\hline & Female & 37 & 18 & 21 & 12 & 12 \\
\hline & Middle-School & 32 & 15 & 21 & 18 & 15 \\
\hline & Secondary & 45 & 19 & 16 & 10 & 10 \\
\hline & College & 40 & 19 & 19 & 13 & 8 \\
\hline
\end{tabular}

The majority (58\%) of KTs seem to have little or very little regrets for buying products or services through SMA, while about only one tenth of them seem to have some regrets for doing so. Little gender variations are observed in this regard. Younger teens seem to have a bit more regrets than older ones when buying products or services over the SMA. For more on privacy and social media refer to [7] and [8].

\subsection{Testing the Existence of the Relationships between the Study Variables and Personal Information}

The chi-square test for independence is used to test whether there is a statistically significant relationship between the study questions with each of the personal data of the Kuwaiti teens, as they appear below.

\subsubsection{SMAs used by Kuwait Teenagers}

Testing the existence of the relationships between the top five SMA used in Kuwait and each of the Kuwait teen's age, gender and educational levels. Using the Chi-square test for independence, we get the following results as shown in the Table 12 below:

Table 12. The p-value for testing the top five SMA used in Kuwait with Age, Gender and Educational Levels

\begin{tabular}{|c|c|c|c|}
\hline \multirow{2}{*}{ SMA } & \multicolumn{3}{|c|}{ P-Value } \\
\cline { 2 - 4 } & Age & Gender & Educational Level \\
\hline WhatsApp & $0.002^{*}$ & 0.533 & $0.045^{*}$ \\
\hline Snapchat & 0.095 & $0.004^{*}$ & $0.019^{*}$ \\
\hline YouTube & 0.098 & 0.071 & $0.019^{*}$ \\
\hline Instagram & $0.018^{*}$ & $0.022^{*}$ & $0.006^{*}$ \\
\hline Twitter & $0.005^{*}$ & 0.336 & 0.072 \\
\hline
\end{tabular}

* Significant at 0.05

Table 12 show that there is a significant relationship between the SMA used and Age in using WhatsApp, Instagram and Twitter at 5\% level of significant. Whereas, there is no relationship between the SMA used and Age in using Snapchat and You Tube at 5\% level of significant.

Also, the Table 12 shows that there is a significant relationship between the SMA used and Gender in using Snapchat and Instagram at 5\% level of significant. Whereas, there is no relationship between the SMA used and Gender in using and WhatsApp and Twitter, You Tube at $5 \%$ level of significant.

In addition, the Table 12 shows that there is a significant relationship between the SMA used and Educational levels in using WhatsApp, Snapchat, You Tube and Instagram at $5 \%$ level of significant. Whereas, there is no relationship between the SMA used and Educational levels in using Twitter, at 5\% level of significant.

\subsubsection{Main Uses of SMA}

Testing the existence of the relationships between why Kuwait teens use SMA and each of the Kuwait teen's age, gender and educational levels. Using the Chi-square test for independence, we get the following results as shown in the Table 13 below.

Table 13 shows that there is a significant relationship between why Kuwait teens use SMA and Age in entertainment only at $5 \%$ level of significant. Whereas, there is no relationship between why Kuwait teens use SMA and Age in all of the following: communication with others, Viewing and exchanging pictures and videos, following up sports, buying and selling products and services, following up fashion, and learning and general education at $5 \%$ level of significant. 
Table 13. The p-value for testing why Kuwait teens use SMA with Age, Gender and Educational Levels

\begin{tabular}{|c|c|c|c|c|}
\hline \multirow{2}{*}{$\begin{array}{c}\text { Q. } \\
\text { No. }\end{array}$} & Usage of SMA & \multicolumn{3}{|c|}{ P-Value } \\
\cline { 3 - 5 } & Age & Gender & $\begin{array}{c}\text { Educational } \\
\text { Level }\end{array}$ \\
\hline 1 & Communication with others & 0.205 & $0.021^{*}$ & $0.038^{*}$ \\
\hline 2 & $\begin{array}{c}\text { Viewing and exchanging } \\
\text { pictures and videos }\end{array}$ & 0.176 & 0.123 & 0.296 \\
\hline 3 & Entertainment & $0.033^{*}$ & $0.014^{*}$ & 0.544 \\
\hline 4 & Following up sports & 0.083 & $0.000^{*}$ & $0.000^{*}$ \\
\hline 5 & $\begin{array}{c}\text { Buying and selling products } \\
\text { and services }\end{array}$ & 0.942 & 0.164 & 0.866 \\
\hline 6 & Following up fashion & 0.540 & $0.000^{*}$ & 0.258 \\
\hline 7 & $\begin{array}{c}\text { Learning and general } \\
\text { education }\end{array}$ & 0.177 & 0.138 & $0.060^{*}$ \\
\hline
\end{tabular}

* Significant at 0.05

Also, the Table 13 shows that there is a significant relationship between why Kuwait teens use SMA and Gender in each of the following: communication with others, entertainment, following up sports, and following up fashion at $5 \%$ level of significant. Whereas, there is no relationship between why Kuwait teens use SMA and Gender in all of the following: viewing and exchanging pictures and videos, buying and selling products and services, and learning and general education at 5\% level of significant.

In addition, the Table 13 shows that there is a significant relationship between why Kuwait teens use SMA and Educational levels in each of the following: communication with others, following up sports, and learning and general education at 5\% level of significant. Whereas, there is no relationship between why Kuwait teens use SMA and Educational levels in all of the following: viewing and exchanging pictures and videos, entertainment, buying and selling products and services, and following up fashion at 5\% level of significant.

\subsubsection{The Time Dimension}

Testing the existence of the relationships between times spent on SMA usage and each of the Kuwait teen's age, gender and educational levels. Using the Chi-square test for independence, we get the following results as shown in the Table 14 below.

Table 14 shows that there is a significant relationship between times spent on SMA usage and Age in What is the average number of hours you sleep each day? at 5\% level of significant. Whereas, there is no relationship between times spent on SMA usage and Age in both items: What is the average time you spend daily using social media applications? and What is the average time you spend daily interacting with your family? at 5\% level of significant.

Table 14. The p-value for testing times spent on SMA usage with Age, Gender and Educational Levels

\begin{tabular}{|c|l|c|c|c|}
\hline \multirow{2}{*}{$\begin{array}{c}\text { Q. } \\
\text { No. }\end{array}$} & \multicolumn{1}{|c|}{ Question } & \multicolumn{3}{|c|}{ P-Value } \\
\cline { 3 - 5 } & $\begin{array}{l}\text { What is the average time you } \\
\text { spend daily using social media } \\
\text { applications? }\end{array}$ & 0.278 & $0.025^{*}$ & 0.093 \\
\hline 9 & $\begin{array}{l}\text { What is the average time you } \\
\text { spend daily interacting with } \\
\text { your family? }\end{array}$ & 0.547 & $0.000^{*}$ & $0.017^{*}$ \\
\hline 10 & $\begin{array}{l}\text { What is the average number of } \\
\text { hours you sleep each day? }\end{array}$ & $0.030^{*}$ & 0.336 & $0.003^{*}$ \\
\hline
\end{tabular}

* Significant at 0.05
Also, Table 14 shows that there is a significant relationship between times spent on SMA usage and Gender in both items: (What is the average time you spend daily using social media applications?) and (What is the average time you spend daily interacting with your family?) at 5\% level of significant. Whereas, there is no relationship between times spent on SMA usage and Gender in (What is the average number of hours you sleep each day?) at $5 \%$ level of significant.

In addition, Table 14 shows that there is a significant relationship between times spent on SMA usage and Educational levels in both items: (What is the average number of hours you sleep each day?) and (What is the average time you spend daily interacting with your family?) at 5\% level of significant. Whereas, there is no relationship between times spent on SMA usage and Educational levels in (What is the average time you spend daily using social media applications?) at 5\% level of significant.

\subsubsection{Impact of Using SMA by Kuwaiti Teens}

Testing the existence of the relationships between the impacts of SMA on Kuwaiti teens and each of the Kuwait teen's age, gender and educational levels. Using the Chisquare test for independence, we get the following results as shown in the Table 15 below:

Table 15. The p-values for testing the impacts of SMA on Kuwaiti teens with Age, Gender and Educational Levels

\begin{tabular}{|c|c|c|c|c|}
\hline \multirow{2}{*}{$\begin{array}{l}\text { Q. } \\
\text { No. }\end{array}$} & \multirow{2}{*}{ Question } & \multicolumn{3}{|c|}{ P-Value } \\
\hline & & Age & Gender & $\begin{array}{l}\text { Educational } \\
\text { Level }\end{array}$ \\
\hline 11 & $\begin{array}{l}\text { Does using SMA affect your } \\
\text { sleeping hours? }\end{array}$ & 0.247 & 0.194 & 0.439 \\
\hline 12 & $\begin{array}{l}\text { Does SM negatively affect } \\
\text { your studying? }\end{array}$ & 0.178 & $0.003^{*}$ & 0.098 \\
\hline 13 & $\begin{array}{l}\text { Does SM negatively affect } \\
\text { your eating habits? }\end{array}$ & 0.175 & $0.005^{*}$ & 0.178 \\
\hline 14 & $\begin{array}{l}\text { Do you consider SM the } \\
\text { best mean to communicate } \\
\text { with your family? }\end{array}$ & $0.041^{*}$ & 0.393 & $0.016^{*}$ \\
\hline 15 & $\begin{array}{l}\text { Do you agree that SM is the } \\
\text { easiest way to make new } \\
\text { relationships with others? }\end{array}$ & 0.347 & 0.131 & $0.022^{*}$ \\
\hline 16 & $\begin{array}{l}\text { To what extend you trust the } \\
\text { information you obtain from } \\
\text { SM? }\end{array}$ & 0.204 & 0.073 & $0.005^{*}$ \\
\hline 17 & 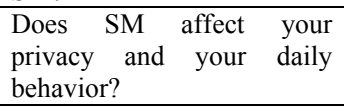 & 0.278 & $0.005^{*}$ & 0.485 \\
\hline 18 & $\begin{array}{l}\text { To what extend do you buy } \\
\text { products or services through } \\
\text { SM? }\end{array}$ & 0.128 & 0.637 & 0.219 \\
\hline 19 & $\begin{array}{l}\text { To what extend did you buy } \\
\text { products or services that you } \\
\text { did not actually need } \\
\text { through SM? }\end{array}$ & 0.603 & 0.421 & 0.186 \\
\hline
\end{tabular}

* Significant at 0.05

Table 15 shows that there is a significant relationship between the impacts of SMA on Kuwaiti teens and Age in: "Do you consider SM the best mean to communicate with your family?" at 5\% level of significant. Whereas, there is no relationship between the impacts of SMA on Kuwaiti teens and Age in the following items: "Does using SMA affect your sleeping hours?", "Does SM negatively affect your studying?", "Does SM negatively affect your eating 
habits?", "Do you agree that SM is the easiest way to make new relationships with others?", "To what extend you trust the information you obtain from SM?", "Does SM affect your privacy and your daily behavior?", "To what extend do you buy products or services through SM?", and "To what extend did you buy products or services that you did not actually need through SM?" at $5 \%$ level of significant.

Also, Table 15 shows that there is a significant relationship between the impacts of SMA on Kuwaiti teens and Gender in the following items: "Does SM negatively affect your studying?", "Does SM negatively affect your eating habits?", and "Does SM affect your privacy and your daily behavior?" at 5\% level of significant. Whereas, there is no relationship between the impacts of SMA on Kuwaiti teens and Gender in the following items: "Does using SMA affect your sleeping hours?", "Do you consider SM the best mean to communicate with your family?", "Do you agree that SM is the easiest way to make new relationships with others?", "To what extend you trust the information you obtain from SM?", "To what extend do you buy products or services through SM?", and "To what extend did you buy products or services that you did not actually need through SM?" at 5\% level of significant.

In addition, Table 15 shows that there is a significant relationship between the impacts of SMA on Kuwaiti teens and Educational levels in the following items: "Do you consider SM the best mean to communicate with your family?", "Do you agree that SM is the easiest way to make new relationships with others?", and "To what extend you trust the information you obtain from SM?" at $5 \%$ level of significant. Whereas, there is no relationship between the impacts of SMA on Kuwaiti teens and Educational levels in the following items: "Does using SMA affect your sleeping hours?", "Does SM negatively affect your studying?", "Does SM negatively affect your eating habits?", "Does SM affect your privacy and your daily behavior?", "To what extend do you buy products or services through SM?", and "To what extend did you buy products or services that you did not actually need through SM?" at 5\% level of significant.

\subsection{Statistical Differences Tests}

The one-way analysis of variance (ANOVA) technique is used to test whether there is a statistically significant difference among the mean responses of study questions for each of the fundamental elements of the study data according to each personal element of the Kuwaiti teens, as well as to identify these differences, if it exists, as they appear below.

\subsubsection{SMAs used by Kuwait Teenagers}

The following Table 16 summarizes the results for testing the differences among the mean responses for the use of each SMA in Kuwait according to Kuwait teens' gender and according to their educational levels.

Using the results of the t-test in the above Table 16 for testing the differences between the mean responses for the use of each SMA, we see there is a significant difference between male and female in using the snapchat and Instagram at $5 \%$ level of significant, were the males use the Instagram more than females whereas females use snapchat more than males. The results also, show that no significant difference between males and females in using the other SMA, the WhatsApp, YouTube, and twitter.

Table 16. The p-values for testing the top five SMA used in Kuwait according to the Kuwait teens' Gender and Educational levels.

\begin{tabular}{|c|c|c|}
\hline \multirow{2}{*}{ SMA } & \multicolumn{2}{|c|}{ P-Value } \\
\cline { 2 - 3 } & Gender $^{(1)}$ & Educational Level $^{(2)}$ \\
\hline WhatsApp & 0.735 & $0.045^{*}$ \\
\hline Snapchat & $0.000^{*}$ & $0.006^{*}$ \\
\hline YouTube & 0.634 & $0.001^{*}$ \\
\hline Instagram & $0.009^{*}$ & 0.114 \\
\hline Twitter & 0.871 & $0.003^{*}$ \\
\hline
\end{tabular}

* Significant at 0.05

(1) p-values using the t-test, since we have two types.

(2) p-values using the ANOVA analysis, since we have three types.

Also, using the results of the ANOVA test in Table 16 for testing the differences among the mean responses for the use of each SMA, we see there is a significant difference among educational levels in using all SMA at $5 \%$ level of significant except for using the Instagram, the results show that there is no significant difference among the educational levels at $5 \%$ level of significant since the p-value is 0.114. More specifically, using the LSD multiple comparisons tests, we found the following:

1. There is a significant difference in using WhatsApp between each of the Mid-School level and High-School level with the College level since the p-values are 0.019 and 0.045, respectively, were both the Mid-School and the High-School levels used WhatsApp more than the College level.

2. There is a significant difference in using Snapchat between the High-School levels with the College level since the p-values is 0.001 , were the High-School level used Snapchat more than the College level.

3. There is a significant difference in using You Tube between the Mid-School level with each of the HighSchool level and College level since the p-values are 0.007 and 0.000 , respectively, were both the High-School levels and the College level used You Tube more than the Mid-School.

4. There is a significant difference in using Twitter between each of the Mid-School level and High-School level with the College level since the p-values are 0.002 and 0.004, respectively, were both the Mid-School and the High-School levels used You Tube more than the College level.

\subsubsection{SMA's Use and Impact on Teens by Age}

The following Table 17 summaries the analysis of variance ANOVA for testing the significant differences among the mean responses of both categories "Why Kuwaiti teens use SMA?" and "Impacts of SMA on Kuwaiti teens" according to their ages.

Table 17 shows that there are no significant differences among the mean responses for both categories: "Why Kuwaiti teens use SMA?" and "Impacts of SMA on Kuwaiti teens" according to the Kuwait teens' gender at $5 \%$ level of significant since their p-values are .488 and .101 , respectively. 
Table 17. The ANOVA table for both categories according to Kuwait teens' age

\begin{tabular}{|c|c|c|c|c|c|c|}
\hline ن. & 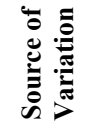 & 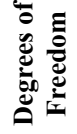 & 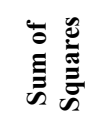 & 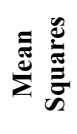 & 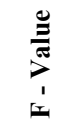 & 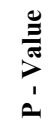 \\
\hline \multirow{2}{*}{$\begin{array}{c}\text { Why } \\
\text { Kuwaiti } \\
\text { teens use } \\
\text { SMA? }\end{array}$} & $\begin{array}{c}\text { Factor } \\
\text { Error }\end{array}$ & $\begin{array}{c}6 \\
396\end{array}$ & $\begin{array}{c}1.670 \\
121.230\end{array}$ & $\begin{array}{l}.278 \\
306\end{array}$ & $\begin{array}{l}.909 \\
---\end{array}$ & $\begin{array}{c}.488 \\
---\end{array}$ \\
\hline & Total & 402 & 122.900 & --- & --- & --- \\
\hline \multirow{3}{*}{$\begin{array}{c}\text { Impacts } \\
\text { of SMA } \\
\text { on } \\
\text { Kuwaiti } \\
\text { teens }\end{array}$} & Factor & 6 & 3.354 & .559 & 1.786 & .101 \\
\hline & Error & 396 & 123.963 & .313 & --- & --- \\
\hline & Total & 402 & 127.322 & --- & --- & --- \\
\hline
\end{tabular}

\subsubsection{SMA's Use and Impact on Kuwait Teens by Gender}

The following Table 18 summaries the analysis of variance ANOVA for testing the significant differences among the mean responses of both categories "Why Kuwaiti teens use SMA?" and "Impacts of SMA on Kuwaiti teens" according to their gender:

Table 18. The ANOVA table for both categories according to Kuwait teens' gender

\begin{tabular}{|c|c|c|c|c|c|c|}
\hline 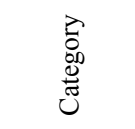 & 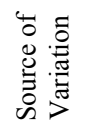 & 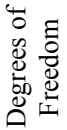 & 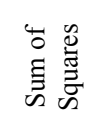 & 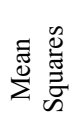 & $\begin{array}{l}\stackrel{0}{ٍ} \\
\stackrel{\pi}{7} \\
1 \\
1\end{array}$ & $\begin{array}{l}\frac{0}{3} \\
\frac{\pi}{7} \\
1 \\
D^{1}\end{array}$ \\
\hline \multirow{3}{*}{$\begin{array}{c}\text { Why } \\
\text { Kuwaiti } \\
\text { teens use } \\
\text { SMA? }\end{array}$} & Factor & 1 & .356 & .356 & 1.163 & .281 \\
\hline & Error & 401 & 122.545 & .306 & --- & --- \\
\hline & Total & 402 & 122.900 & --- & --- & --- \\
\hline \multirow{3}{*}{$\begin{array}{c}\text { Impacts of } \\
\text { SMA on } \\
\text { Kuwaiti } \\
\text { teens }\end{array}$} & Factor & 1 & .259 & .259 & .816 & .367 \\
\hline & Error & 401 & 127.063 & .317 & --- & --- \\
\hline & Total & 402 & 127.322 & --- & --- & --- \\
\hline
\end{tabular}

The above Table 18 shows that there are no significant differences among the mean responses for both categories: "Why Kuwaiti teens use SMA?" and "Impacts of SMA on Kuwaiti teens" according to the Kuwait teens' gender at $5 \%$ level of significant since their p-values are .281 and .367 , respectively.

\subsubsection{SMA's Use and Impact on Teens by Education Level}

The following Table 19 summaries the analysis of variance ANOVA for testing the significant differences among the mean responses of both categories "Why Kuwaiti teens use SMA?" and "Impacts of SMA on Kuwaiti teens" according to their education levels.

Table 19 shows that there are no significant differences among the mean responses for the category: "Why Kuwaiti teens use SMA?" according to the Kuwait teens' educational levels at $5 \%$ level of significant since the $p$ values is .914 , whereas, there is a significant differences among the mean responses for the category: "Impacts of SMA on Kuwaiti teens" according to the Kuwait teens' educational level at $5 \%$ level of significant since the $\mathrm{p}$-value is .021. More specifically, according to LSD multiple comparison tests, we see that there is a significant difference between the mean responses of impacts of SMA on Kuwaiti teens for middle-school level and college level at $5 \%$ level of significant since the p-value is equal to 0.005 .

Table 19. The ANOVA table for both categories according to teens' educational levels

\begin{tabular}{|c|c|c|c|c|c|c|}
\hline 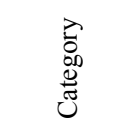 & 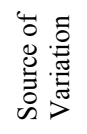 & 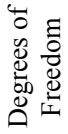 & 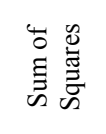 & 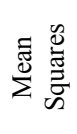 & 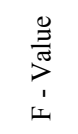 & $\begin{array}{l}\frac{0}{3} \\
\stackrel{\pi}{7} \\
1 \\
2^{\prime}\end{array}$ \\
\hline \multirow{3}{*}{$\begin{array}{c}\text { Why } \\
\text { Kuwaiti } \\
\text { teens use } \\
\text { SMA? }\end{array}$} & Factor & 2 & .055 & .028 & .090 & .914 \\
\hline & Error & 400 & 122.845 & .307 & --- & --- \\
\hline & Total & 402 & 122.900 & --- & --- & --- \\
\hline \multirow{3}{*}{$\begin{array}{c}\text { Impacts of } \\
\text { SMA on } \\
\text { Kuwaiti } \\
\text { teens }\end{array}$} & Factor & 2 & 2.448 & 1.224 & 3.921 & $.021^{*}$ \\
\hline & Error & 400 & 124.874 & .312 & --- & --- \\
\hline & Total & 402 & 127.322 & --- & --- & --- \\
\hline
\end{tabular}

* Significant at 0.05 .

\section{Conclusions}

In light of the discussion of the results of this study, the results are quite interesting because they quantify a number of issues related to Kuwaiti teenager's behavior with regard to the use of SMA. Perhaps the most outstanding results are can be summarized as follows:

1. The top SMA used by KTs is WhatsApp and Snapchat, respectively, with clear preference of Snapchat for females and WhatsApp for males.

2. SMA occupies a significant portion of KTs time. The majority of teens use on average SMA more than three hours a day.

3. The top-2 use of SMA by KTs are communication with others and entertainment.

4. Nearly half of the KTs surveyed feel that the use of SMA has negatively affected their sleeping hours.

5. KTs, especially male ones, spend less time interacting with their families than the time they spend using SMA.

6. On the positive side, about half of the KTs found SMA a great resource for learning and following up on new things.

7. The majority of KTs do not consider SMA a substitute for face-to-face interaction with family members.

8. No statistically significant evidence was found to support that the use of SMA negative impacts KTs eating habits.

9. KTs level of trust of the information obtained from SMA is quite mixed.

10. The vast majority of KTs do not seem to be concerned with privacy issues related to the use of SMA.

11. More than one third of KTs buy products or service as using SMAs and they are generally satisfied with their purchases.

\section{Acknowledgments}

The author would like to thank all of the students who assisted in all stages of executing this study and would like to extend thanks to the Ministry of Education in 
Kuwait for facilitating the distribution of the questionnaire to middle and secondary schools in Kuwait.

\section{References}

[1] Lenhart A, Purcell K, Smith A, Zickur K. Social Media and Young Adults. Washington, DC: Pew Research Center; 2010. (Available at: http://pewinternet.org/Reports/2010/Social-Media-and-YoungAdults.aspx. Accessed July 16, 2010).

[2] Mohamed El Khouli, The Most Important Negative Aspects of Using Social Networking Affecting the Family Stability in Abu Dhabi-A Pilot Study. International Journal of Engineering and Technology 5.1 (Feb 2013): 85.

[3] Gwenn Schurgin O'Keeffe, Kathleen Clarke-Pearson. The Impact of Social Media on Children, Adolescents, and Families. Council on Communications and Media

[4] Jamal J. Al-Menayes. Dimensions of Social Media Addiction among University Students in Kuwait. Psychology and Behavioral Sciences. Vol. 4, No. 1, 2015, pp. 23-28.
[5] AH Sahar, A Khudadah. Availability and usage of information and communication technologies statistics and their impacts: the case of Kuwait. Central Statistical Bureau Kuwait, 2012 - itu.int.

[6] Irvine C. Excessive chatting on Facebook can lead to depression in teenage girls. Daily Telegraph.January31, 2010. (Available at: www.telegraph.co.uk/technology/facebook/ 4405741/Excessivechatting-on-Facebook-can-lead-to-depression-in-teenagegirls.html).

[7] Barnes S. A privacy paradox: social networking in the United States. First Monday. 2006; 11(9). (Available at: http://firstmonday.org/htbin/cgiwrap/

bin/ojs/index.php/fm/article/view/1394/1312. Accessed July 16, 2010).

[8] Madden M, Lenhart A, Cortesi S, Gasser U, Duggan M, Smith A, Beaton M (2013). Teens, social media, and privacy. Pew Research Center. (Available at

http://www.pewinternet.org/ /media//Files/Reports/2013/PIP_ TeensSocialMediaand- Privacy.pdf). 